\title{
Impaired larval development at low salinities could limit the spread of the non-native crab Hemigrapsus takanoi in the Baltic Sea
}

\author{
Ola Mohamed Nour ${ }^{1,2, *}$, Christian Pansch ${ }^{3}$, Mark Lenz ${ }^{1}$, Martin Wahl ${ }^{1}$, \\ Catriona Clemmesen ${ }^{1}$, Meike Stumpp ${ }^{4}$ \\ ${ }^{1}$ Department of Marine Ecology, GEOMAR Helmholtz Centre for Ocean Research Kiel, Düsternbrooker Weg 20, 24105 Kiel, Germany \\ ${ }^{2}$ Department of Biology and Geology, Faculty of Education, Alexandria University, 21526 Alexandria, Egypt \\ ${ }^{3}$ Environmental and Marine Biology, Åbo Akademi University, Artillerigatan 6, 20520 Åbo, Finland \\ ${ }^{4}$ Zoological Institute, Christian-Albrechts University, 24118 Kiel, Germany
}

ABSTRACT: The Asian shore crab Hemigrapsus takanoi, native to the northwest Pacific Ocean, was recently discovered in Kiel Fjord (southwestern Baltic Sea). In laboratory experiments, we tested the salinity tolerance of $H$. takanoi across 8 levels $(0$ to 35) and across 3 life history stages (larvae, juveniles and adults) to assess its potential to invade the brackish Baltic Sea. Larval development at different salinities was monitored from hatching to the megalopa stage, while survival and feeding of juveniles and adults were assessed over $17 \mathrm{~d}$. Larvae of $H$. takanoi were able to complete their development to megalopa at salinities $\geq 20$ and the time needed after hatch to reach this stage did not differ between salinities of $20,25,30$ and 35 . At a salinity of 15, larvae still reached the last zoea stage (zoea V), but development to the megalopa stage was not completed. All juveniles and adults survived at salinities from 5 to 35. Feeding rates of juveniles increased with increasing salinity across the entire salinity range. However, feeding rates of adults reached their maximum between salinities of 15 and 35 . Our results indicate that both juveniles and adults of $H$. takanoi are euryhaline and can tolerate a wide range of salinities, at least for the time period tested ( $2 \mathrm{wk})$. However, larval development was impaired at salinities lower than 20, which may prevent the spread of $H$. takanoi into the Baltic Proper.

KEY WORDS: Salinity · Larval development . Non-native species $\cdot$ Kiel Fjord · Asian brush-clawed shore crab $\cdot$ Invasion potential

\footnotetext{
${ }^{*}$ Corresponding author: olasm.nour@gmail.com
}

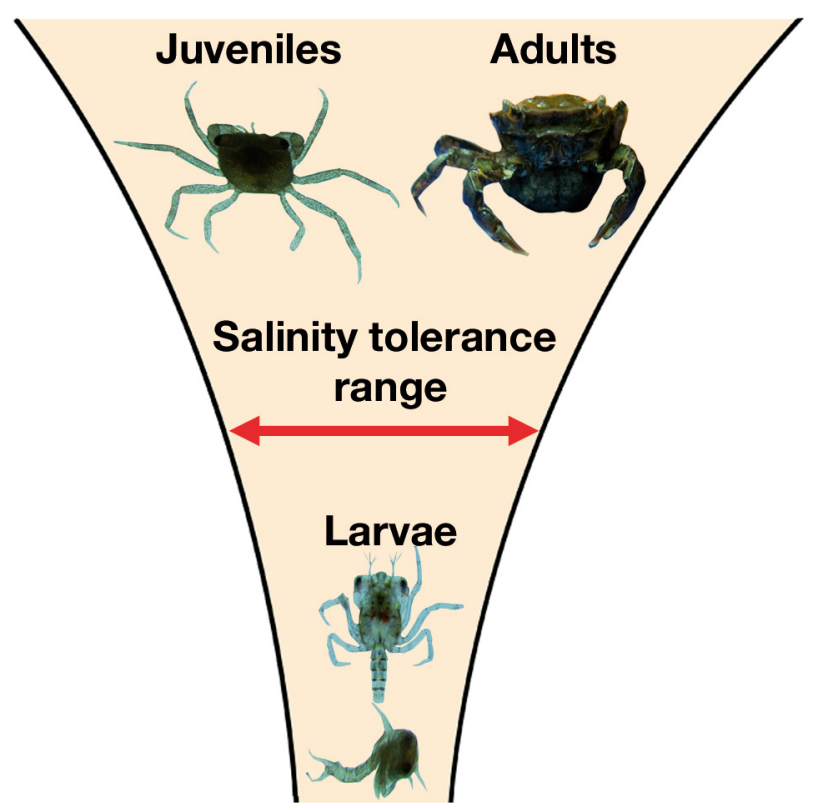

Schematic model of the salinity tolerance of different ontogenetic stages of Hemigrapsus takanoi from the southwestern Baltic Sea.

Image: O. M. Nour (modified from Walther et al. 2010)

\section{INTRODUCTION}

Introduction of non-native species is among the most serious threats to the conservation of biodiversity and ecosystem integrity worldwide (OcchipintiAmbrogi \& Galil 2010). Many factors currently facilitate

() The authors 2021. Open Access under Creative Commons by Attribution Licence. Use, distribution and reproduction are unrestricted. Authors and original publication must be credited. 
the expansion of species beyond their natural habitats. Among them, the most important are the increasing globalization of international trade, tourism/travel and human population growth (Canning-Clode 2016).

Non-native species are considered invasive when they establish new populations, reproduce successfully, proliferate, and affect their new environment (Occhipinti-Ambrogi \& Galil 2010). In order to establish self-sustaining populations in a new area, a species must pass through a series of successive steps (Lockwood \& Somero 2011): (1) an establishment phase that is characterized by low abundance of the introduced species, (2) an expansion phase, which makes the introduced species a dominant component with strong effects on the invaded system and (3) an adjustment phase, which starts when the introduced species shows behavioural and evolutionary adaptation to the abiotic and biotic conditions of its new habitat (identified and described by Reise et al. 2006).

European waters are severely affected by introduced species (Galil et al. 2014). The Baltic Sea is one of the largest brackish water bodies in the world and is home to 152 non-native and cryptogenic species (supplementary material of Tsiamis et al. 2019). The Baltic Sea is characterized by a strong salinity gradient (Leppäkoski et al. 2002). The surface water salinity ranges from $\sim 2-4$ in the northeast to 6-8 in the central Baltic Proper, 15-25 in the southwest and >18-33 in the Danish straits and the Kattegat (Krauss 2001).

The generally strong environmental fluctuations in the Baltic Sea system, which are caused by natural conditions such as the salinity-temperature gradient, and which have facilitated pronounced impacts of human-mediated stressors (warming, desalination, overfishing and eutrophication), make the Baltic Sea extremely susceptible to invasions by new species (Paavola et al. 2005, Reusch et al. 2018).

Invasive species often show high physiological tolerance of different environmental stressors, such as warming, desalination, reduced light availability, hypoxia and pollution, which is assumed to be an important prerequisite for invasion success (Lenz et al. 2011, Paiva et al. 2018). Salinity is one of the most important environmental factors controlling survival, reproduction and growth in aquatic organisms, as well as their geographical distribution, in particular in marginal seas (Anger 2003, Thomsen et al. 2018). Salinity is also the main factor that determines a species' invasion success in Baltic Sea habitats (Jaspers et al. 2011, Paiva et al. 2018). Tolerance to low salinities can therefore be used as a measure for assessing the potential of a species to invade the Baltic Sea area, and other comparable habitats (Hudson et al. 2018,
Reusch et al. 2018). Even short-term fluctuations in salinity could impair successful planktonic larval development in many species (Anger 2003). For example, the low salinity in the central Baltic Sea is supposed to restrict the expansion potential of the invasive comb jelly Mnemiopsis leidyi in the southeastern regions, since its reproductive ability decreases under low salinity conditions (Jaspers et al. 2011).

Some invasive species expand their salinity tolerance window during the invasion process (Charmantier et al. 2002); others narrow their salinity range in their introduced compared to their native regions, and are therefore not able to thrive in brackish water habitats (Pauli \& Briski 2018). Consequently, species with a broad salinity tolerance may have a higher probability of establishment in new habitats, particularly in variable environments with fluctuating salinities (Lenz et al. 2011). In addition to this broad species-specific tolerance (Paiva et al. 2018, Pauli \& Briski 2018), tolerance to low salinities can differ between ontogenetic stages of the same species (Charmantier 1998, Anger et al. 2008). Embryos and larvae of marine decapod crustaceans, for example, are often more sensitive to osmotic stress than juveniles and adults (Bas \& Spivak 2000) because they lack specific ion regulatory epithelia such as gills (Charmantier et al. 1998). Therefore, adaptations to extreme salinity regimes at all life history stages are necessary for the successful establishment of a species in a brackish environment (Charmantier 1998).

A crustacean recently introduced into the brackish Baltic Sea is the Asian brush-clawed shore crab Hemigrapsus takanoi (Asakura \& Watanabe 2005). This species, which is native to the northwest Pacific Ocean, inhabits muddy and rocky shores as well as sheltered harbours and estuaries (Gollasch 1998), but can also be found on soft sediments in the subtidal (Asakura \& Watanabe 2005). Adult $H$. takanoi from native regions are known to be euryhaline and tolerate a broad salinity range from 7 to 35 (Mingkid et al. 2006a). The first record of $H$. takanoi in Europe was in 1993 in the German North Sea, when several individuals were found on ship hulls in Bremerhaven Harbour (Gollasch 1998). The species subsequently extended its range and reached the coasts of France, Spain and Belgium, as well as the Dutch and German Wadden Sea (Gittenberger et al. 2010 and references therein). Today, it is also known from the western part of the English Channel, and from North Kent and Essex in Great Britain (Ashelby et al. 2017 and references therein). In the southwestern Baltic Sea (Kiel Fjord), H. takanoi was first recorded in summer 2014 (Geburzi et al. 2015).

In the southwestern Baltic Sea, H. takanoi might alter the existing ecosystem (Geburzi et al. 2015) by 
competing with the 2 main benthic invertebrate predators, the starfish Asterias rubens and the shore crab Carcinus maenas, for the same food source, i.e. the blue mussel Mytilus edulis (Reusch \& Chapman 1997). However, to predict whether H. takanoi can establish a stable population in the southwestern Baltic Sea, and whether it can spread further into the Baltic Proper, precise knowledge of its salinity tolerance across the full reproductive cycle is essential. Although only limited information is available for northern Europe (but see van den Brink et al. 2012), juveniles and adults of $H$. takanoi in the species' native range have been observed in waters with salinities as low as 7 to 9 (Mingkid et al. 2006a, Gittenberger et al. 2010). This is surprising, since laboratory experiments with individuals from Tokyo Bay only showed successful development from megalopa to juvenile at salinities $\geq 25$ (Mingkid et al. 2006b).

The present study determined the influence of a wide range of salinities on survival and feeding in different life history stages of $H$. takanoi. We monitored the developmental success of larvae to the megalopa stage and assessed food intake of juveniles and adults. Individuals from a population that was discovered in 2014 in Kiel Fjord (salinity around 15) were exposed to 8 levels of salinity, from freshwater (0) to fully marine conditions (35) to elucidate the species' potential to establish a stable population in this region, and to further invade the Baltic Proper. In addition, a salinity dataset, collected in Kiel Fjord over $13 \mathrm{yr}$, was used to (1) assess salinity ranges and variability in this region, (2) correlate salinity with larval development and juvenile settlement success in Kiel Fjord and (3) predict the dispersal capacity of H. takanoi towards the Baltic Proper.

\section{MATERIALS AND METHODS}

\subsection{Survival and development of larvae}

Ovigerous female Hemigrapsus takanoi, which usually bury themselves in the muddy bottom of the fjord or hide in mussel Mytilus edulis beds (Geburzi et al. 2015, Nour et al. 2020), were collected by scraping mussel aggregates from pilings and from the bottom of the inner Kiel Fjord $\left(54^{\circ} 32.9^{\prime} \mathrm{N}_{i} 10^{\circ} 14.8^{\prime} \mathrm{E}\right)$ between mid-July and early August 2017. To identify females with eggs close to hatching, a small sample of eggs (20-30) was isolated carefully from each individual female using a fine sterilized tweezer. The samples were then investigated under a dissecting stereomicroscope (Olympus SZ51). Four females with carapace widths of $17.3 \pm 0.8 \mathrm{~mm}($ mean $\pm \mathrm{SD})$, which had broods with almost $10 \%$ yolk, prominent eye spots, and fully developed zoeae close to hatch (van den Brink et al. 2013), were used to study larval development under different salinity regimes. Each female was reared in an individual 21 plastic aquarium filled with aerated seawater of the same salinity as the Kiel Fjord at the time of collection (15-16.7), at a temperature of $20 \pm 0.5^{\circ} \mathrm{C}$ and a photoperiod of $12 \mathrm{~h}: 12 \mathrm{~h}$ (light:dark). Water was exchanged daily and females were offered crushed mussels ad libitum twice per week until larval hatching. The duration from capturing the female crabs to the hatching of embryos never exceeded $2 \mathrm{wk}$.

Eight salinity levels $(0,5,10,15,20,25,30$ and 35$)$ were adjusted using filtered (0.2 $\mu \mathrm{m}$ millipore) and aerated North Sea water (salinity $\sim 33$ ). Salinities between 5 and 30 were obtained by diluting the seawater with appropriate amounts of deionized tap water (Epifanio et al. 1998, Bas \& Spivak 2000), while for the highest salinity (35), artificial sea salt (SeequaSal) was added. Although diluting seawater may lead to a reduction in nutrient concentrations mainly at low salinities, this is a common method used in salinity assays on Brachyura (e.g. Charmantier et al. 2002, Anger et al. 2008) and should not have an effect on the crabs. For freshwater conditions (salinity $=0$ ), we used deionized tap water. For salinities from 5 to 30 , the seawater $\mathrm{pH}$ was slightly reduced due to the decreased bicarbonate levels of the added deionized water. We adjusted $\mathrm{pH}_{\mathrm{NBS}}$ ( $\mathrm{pH}$ at the NBS scale) to a value of $\sim 7.9$, resembling Kiel Fjord's $\mathrm{pH}_{\mathrm{NBS}}$ during crab collection (see also Thomsen et al. 2015 for Kiel Fjord carbonate chemistry), using $1 \mathrm{M}$ sodium bicarbonate solution (Thomsen et al. 2018). $\mathrm{pH}_{\mathrm{NBS}}$ values were measured with a WTW $3310 \mathrm{pH}$-meter equipped with a SenTix $81 \mathrm{pH}$ electrode. Salinity was adjusted using a WTW Cond 3110 equipped with a Tetracon 325 electrode.

Immediately after hatching, actively swimming zoea I larvae were transferred into individual $100 \mathrm{ml}$ culture vials filled with $80 \mathrm{ml}$ of seawater using widebore pipettes. For each salinity, ten $100 \mathrm{ml}$ vials, each containing an initial number of 10 zoea I larvae, were used. This setup was repeated for each of the 4 female crabs. In total, the experiment included 320 vials ( 8 salinities $\times 4$ females $\times 10$ vials). Larvae were cultured from zoea I to the megalopa stage without aeration, but with open lids (de Jesus de Brito Simith et al. 2012) at $20 \pm 0.5^{\circ} \mathrm{C}, \mathrm{pH} 7.9 \pm 0.1$ and a photoperiod of $12 \mathrm{~h}: 12 \mathrm{~h}$ (light:dark). The water in each of the vials was exchanged daily. On these occasions, larvae were checked for mortality, as well as for moult, and 
were provided freshly hatched $(<100 \mu \mathrm{m})$ brine shrimp Artemia spp. nauplii (Great Salt Lake Brand), at a density of $\sim 10$ nauplii per ml seawater (Anger et al. 2008). To avoid changes in experimental salinities, Artemia spp. were rinsed with water of the same salinity level prior to being added to culture vials (de Jesus de Brito Simith et al. 2012). Moulting was checked by inspecting the vials for exuviae (for zoeae II to V) and was confirmed by microscopy (for zoeae IV and V) based on morphology (after Landeira et al. 2019; see Fig. S1a,b in the Supplement at www.int-res. com/articles/suppl/b030p085_supp.pdf). Megalopae could be observed without microscopic inspection due to their large size and distinct morphology (Fig. S1c). The experiment continued until the last zoea larva at each salinity level had either died or moulted into a megalopa. Overall developmental success was determined by counting those larvae that successfully moulted into megalopae in each vial. The median time (in d) needed by larvae for development from hatching to the megalopa stage at each salinity level was used as an indicator of larval development duration.

\subsection{Survival and feeding rates of juveniles and adults}

Juvenile (5.8-6.9 mm carapace width) and adult female (16.7-23.2 mm carapace width; Geburzi et al. 2018) H. takanoi were collected in November 2018 as described above. They were kept in the laboratory under seawater conditions present in Kiel Fjord at the time of collection $(20 \pm 0.5)$, at $12 \pm 0.5^{\circ} \mathrm{C}$ and a photoperiod of $10 \mathrm{~h}: 14 \mathrm{~h}$ (light:dark). All collected individuals had a hard carapace (i.e. they were in the intermoult stage). Water was exchanged daily and crabs were fed crushed mussels ad libitum. In addition to mussels, frozen amphipods Gammarus spp. and shrimps Palaemon spp. were provided for juveniles. Salinity levels $(0,5,10,15,20,25,30$ and 35) were adjusted as described above. The different salinity treatments were in 601 tanks and were well-aerated. Two weeks after acclimation to laboratory conditions, a total of 40 juveniles ( $\mathrm{n}=5$ crabs per salinity level) and 24 adults ( $n=3$ crabs per salinity level) with intact appendages were selected for the experiment. Only 3 adult crabs were used at each treatment level due to the lack of availability of adult crabs in the field at the time of the experiment. Juveniles and adults had carapace widths of $6.45 \pm 0.32$ (mean \pm SD) and 19.98 $\pm 1.65 \mathrm{~mm}$, respectively. Each juvenile was placed separately in a 11 Kautex bottle (filled with 0.51 water), while each adult was placed separately in a
21 plastic aquarium (filled with 11 water). Seawater conditions in the aquaria were changed from $20 \pm 0.5$ (acclimation conditions) to the various target salinities in a stepwise manner at 1.25 salinity units per hour to allow for acclimation. This rate is sufficient for decapod juveniles to reach a constant haemolymph concentration (Charmantier et al. 2002), while the adults of the genus Hemigrapsus spp. are known to cope with low/and or fluctuating salinities without any acclimation (Urzúa \& Urbina 2017, Hudson et al. 2018). After target salinities were reached, the experiments were started and lasted for $17 \mathrm{~d}$.

In a pilot study, we observed that juvenile crabs cannot open living mussels by themselves. However, to ensure a comparable experimental set-up with the same food source as used in the experiments with adults (see below), 3 opened mussels (11.0-11.9 mm) were offered to each individual juvenile crab every other day. Before feeding, all faecal particles were manually removed using disposable transfer pipettes, while the seawater, including remaining mussel shells and soft tissue residues, was filtered through pre-weighed tea bags. Afterwards, the wet filters, including mussel shells and soft tissue residues, were washed quickly with distilled water to eliminate adhesive salt and placed on pre-weighed and numbered aluminium trays. The filters were then dried in a furnace at $60^{\circ} \mathrm{C}$ for $48 \mathrm{~h}$ and dry weight was quantified to the nearest $0.001 \mathrm{~g}$. We assessed food consumption rates of juvenile crabs by quantifying the dry weight (g) of mussel tissue consumed. The dry weight of the mussels offered at the beginning of each trial was estimated by calculating the average dry weight $(\mathrm{g})$ of 21 mussels with a size similar to those used during the feeding trial (11.0-11.9 mm). This was done by placing each of the 21 mussels (including shell and tissues) on a numbered and pre-weighed aluminium tray. The trays with mussels were dried at $60^{\circ} \mathrm{C}$ for $48 \mathrm{~h}$ and weighed. The dry weights of the soft tissue and shell were measured separately. The mean dry soft tissue of the 21 mussels was $0.0080 \pm 0.0004 \mathrm{~g}$ (mean $\pm \mathrm{SD})$, while the mean dry shell weight was $0.0930 \pm 0.0170 \mathrm{~g}$. Consumption rates were calculated as the difference in weight between the mean of the 21 mussels and the mean leftover of the 3 offered mussels during each feeding trial.

Adults of $H$. takanoi were offered 20 closed mussels ranging from 6 to $9 \mathrm{~mm}$ (Nour et al. 2020). Every other day, all mussels were collected, all opened mussels were counted, and 20 new mussels were added.

Throughout the experiment, water was exchanged every other day, while the survival rate (\%) was monitored daily over the $17 \mathrm{~d}$ experimental period. Lack 
of movement even after stimulation with a glass rod, absence of beating activity of scaphognathites (i.e. lack of gill chamber ventilation) and abdomen opening and relaxation (Novo et al. 2005) were considered as signs that an individual had died. Food was offered every other day, while feeding rates were recorded over the entire experimental period. They were assessed as mean mussel dry weight ( $\mathrm{g}$ ) consumed by juveniles, and as the mean number of mussels opened and consumed in the case of adults.

\subsection{Kiel Fjord salinity measurements}

Salinity in Kiel Fjord was recorded on weekly cruises of the research vessel FK Polarfuchs from 2005 to 2018 using a CTD48M probe (Sea and Sun Technology) at a station in front of the GEOMAR pier (Wittlingskuhle, position: $54^{\circ} 20.15^{\prime} \mathrm{N}, 10^{\circ} 9.1^{\prime} \mathrm{E}$ ).

\subsection{Statistical analysis}

All analyses and statistical procedures were performed using the statistical software R (version 3.6.0, $\mathrm{R}$ Development Core Team 2016). To test whether survival rates differed between salinities, the log-rank test, in cases of proportional hazards, or the PetoWilcoxon test for non-proportional hazards were used. Survival rates were visualized by KaplanMeier curves. The Kaplen-Meier method is a nonparametric estimator of survival that incorporates incomplete (censored) observations, such as those cases where larvae or crab had not died by the end of the examined period. Pairwise comparisons of survival rates were done for relevant survival and salinity combinations and $\mathrm{p}$-values were adjusted for multiple testing using the Benjamini-Hochberg $(\mathrm{BH})$ correction. Analyses were performed using the survival and survminer packages in R (Therneau 2015, Kassambara et al. 2019).

Furthermore, we checked for maternal effects on developmental success with a generalized linear mixed model that included identity of the female crabs as a random factor. Since this model revealed that the contribution of the female crabs to the unexplained variation in the data was marginal (less than $1 \%$ ), we concluded that there were no maternal effects and excluded this random factor from further modelling. We then used a linear model (LM) by fitting a $2^{\text {nd }}$ degree polynomial to test whether salinity significantly affected the number of larvae reaching the megalopa stage, time to moult, and feeding rates of both juveniles and adults. The choice of model was based on our expectation that the response variables would, within the range of salinities examined in the experiment, be a unimodal function of salinity. We refrained from fitting alternative models post hoc, i.e. after having collected the data. Since larvae reached the megalopa stage exclusively in salinities from 20 to 35 , we only included these 4 levels and salinity 15 , i.e. the highest salinity at which the megalopa stage was not reached, in the analyses. Since both juveniles and adults died at a salinity of 0 , we obtained no feeding rates for this level. We checked whether the assumptions of the LM were met by inspecting residual plots. In addition, for larval development, the salinities at which response variables were maximized (i.e. larval survival) or minimized (i.e. time needed to reach the megalopa stage) were identified with polynomial curves fitted to the data. This was done for all cases in which salinity significantly affected the examined response variables. Furthermore, we verified whether the optimum point (maximum or minimum) of a given response variable occurred in the range of salinity levels (0-35) used in this study by applying the general quadratic equation as follows (Koram 2019):

$$
y=a x^{2}+b x+c
$$

where $a$ and $b$ are the slopes of $x^{2}$ and $x$, respectively, and $c$ is the intercept of the regression line. We then determined the optimum point as follows:

$x$-coordinate of the vertex (optimum point) $=-b / 2 a$

\section{RESULTS}

\subsection{Survival of larvae, juveniles and adults}

Larvae of Hemigrapsus takanoi completed development to the megalopa stage only when reared in salinities $\geq 20$ (Fig. 1a). Survival rates were significantly different between salinities (Peto-Wilcoxon test: $\chi^{2}=540, \mathrm{df}=7, \mathrm{p} \leq 0.001$; Fig. $1 \mathrm{a}$ ); the median time to death was $1,7,19$ and $33.5 \mathrm{~d}$ for salinities 0 , 5,10 and 15 , respectively. In the salinity range $0-15$, survival steadily declined with decreasing salinity $(15>10>5>0)$ and was clearly different from survival in the salinity range $20-35$.

Juvenile and adult $H$. takanoi showed $100 \%$ survival under all salinities except the freshwater condition (with a salinity of 0 ), under which no individual survived. The median time to death in freshwater was $2 \mathrm{~d}$ for juveniles (log-rank test: $\chi^{2}=39, \mathrm{df}=7$, 
(a)

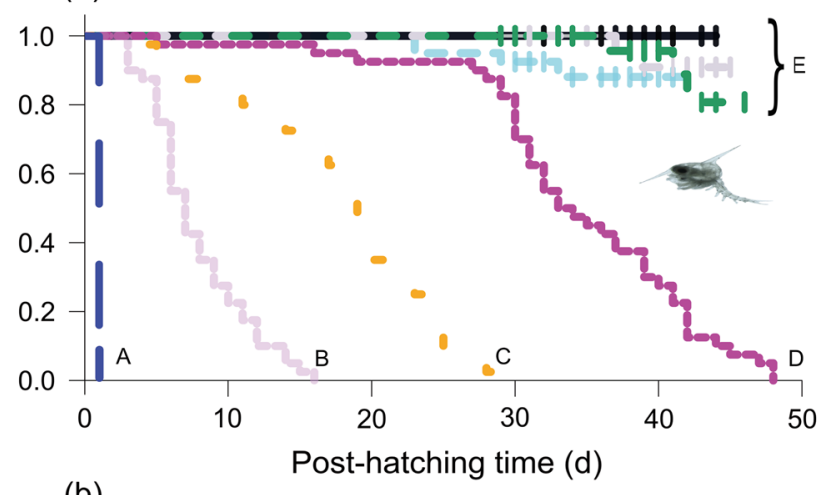

(b)

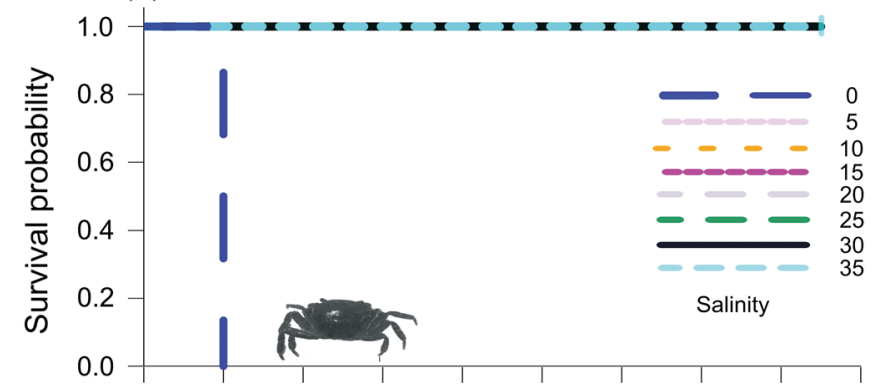

(c)

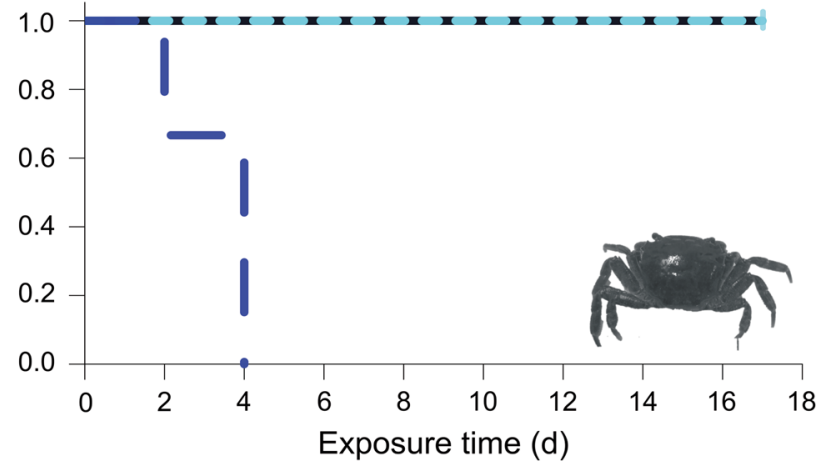

Fig. 1. Influence of salinity (0-35) on survival rates in (a) larvae, (b) juveniles and (c) adults of Hemigrapsus takanoi from Kiel Fjord. Initial numbers of individuals were 400 larvae (100 larvae from each of 4 females), 5 juveniles and 3 adults per salinity level. (a) Marks (I) indicate censored data, i.e. animals reared at the respective salinity levels survived until the end of the experiment or died for reasons other than salinity stress during the experiment. Different lower-case letters indicate significant differences (pairwise Peto and Peto tests, $p \leq 0.05$ ) between experimental groups. All juveniles and adults survived all salinity exposures apart from salinity 0

$\mathrm{p} \leq 0.001$; Fig. $1 \mathrm{~b}$ ) and $4 \mathrm{~d}$ for adults (log-rank test: $\chi^{2}=28, \mathrm{df}=7, \mathrm{p} \leq 0.001$; Fig. 1c).

\subsection{Development of larvae to the megalopa stage}

Although survival rates did not differ between experimental groups in the salinity range between
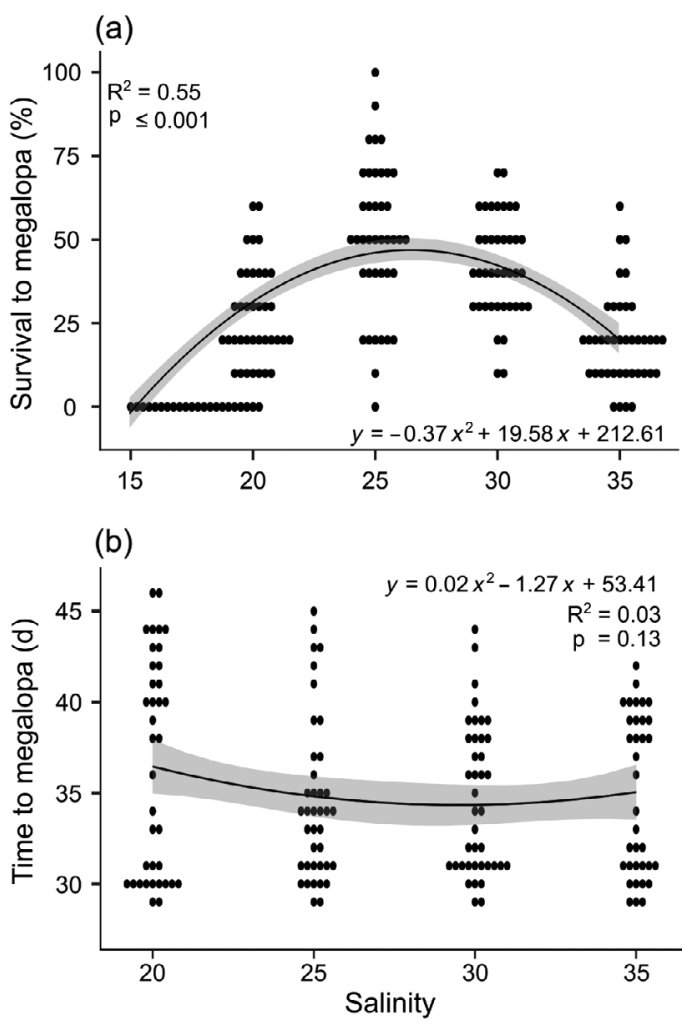

Fig. 2. Influence of salinity (15-35) on (a) the percentage of larvae that reached the megalopa stage, and (b) the time needed to reach this stage in $H$. takanoi from Kiel Fjord. Salinity levels at which larvae did not reach the megalopa stage (i.e. salinities 0-15) were removed from the analysis of time needed to reach the megalopa stage, while salinity of 15 is included in the analysis of survival data. Each black dot represents the proportion of survivors in a single vial with 10 larvae or the mean time needed to reach the megalopa stage in a single vial. $2^{\text {nd }}$ degree polynomials were fitted to the data. Grey areas represent the $95 \%$ confidence intervals of the fitted lines

20 and 35 (pairwise Peto and Peto tests; Table S1), the percentage of larvae that reached the megalopa stage within $50 \mathrm{~d}$ after hatching significantly changed with salinity $\left(2^{\text {nd }}\right.$ degree polynomial regression: $\left.F_{(2,197)}=124, \mathrm{p} \leq 0.001, \mathrm{R}^{2}=0.55\right)$. The highest proportion of larvae successfully developing into megalopae was observed at salinities of 25 and 30 (median proportion was 50 and $40 \%$, respectively; Figs. 2a \& 3), while development success was lower (median survival of $20 \%$ ) at salinities of 20 and 35 (Figs. 2a \& 3). The median time $H$. takanoi larvae needed from hatching to reaching the megalopa stage was $34 \mathrm{~d}$ (salinities 20 and 25), $38 \mathrm{~d}$ (salinity 30 ), and $33.5 \mathrm{~d}$ (salinity 35 ). However, unlike the percentage of larvae reaching the megalopa stage, this development time did not change significantly with 
(a)

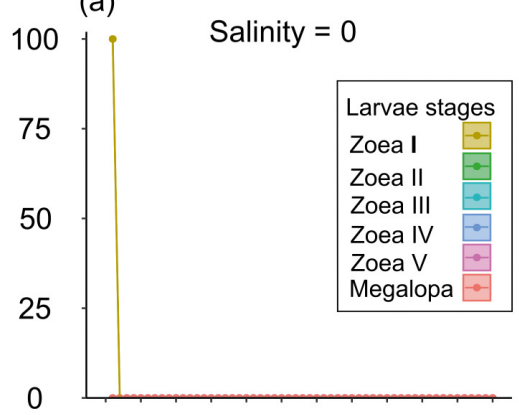

(c)

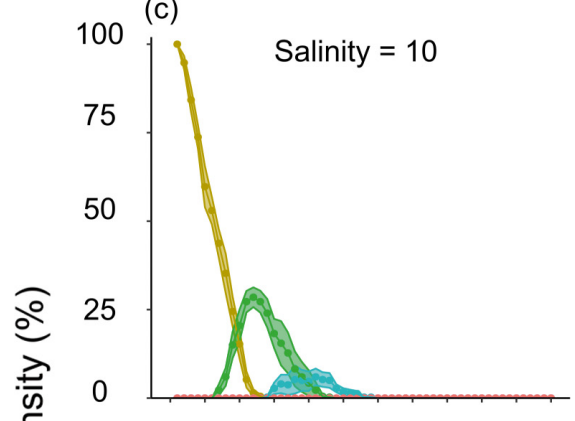

(e)

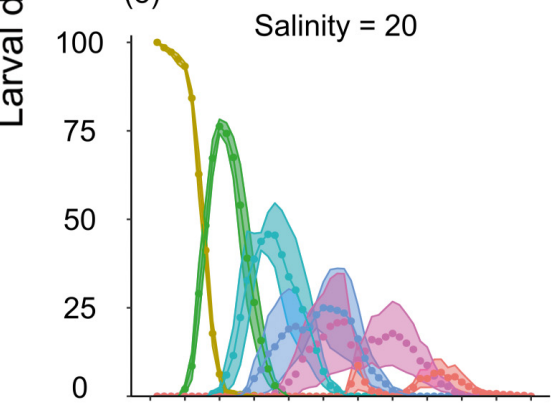

(g)

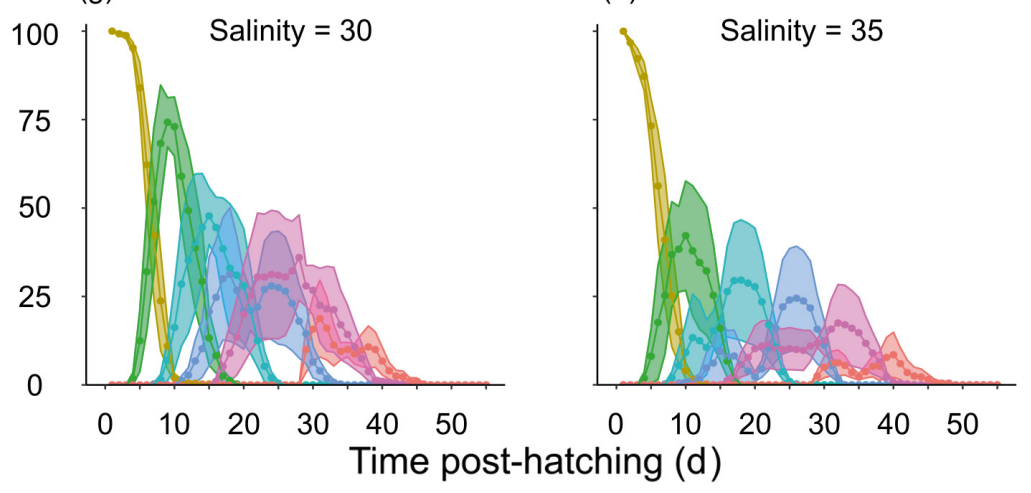

Fig. 3. Influence of salinity $(0-35, \mathrm{a}-\mathrm{h})$ on the percentage of $H$. takanoi larvae reaching the next larval stage during the experiment. Percentage of zoea I that reached zoea II are based on the initial 10 larvae per vial. For the remaining observations (from zoea II to the megalopa stage), percentages are based on the number of individuals that reached the previous stage. The circles correspond to the replicates ( $\mathrm{n}=4$ females used) and shaded areas define the $95 \%$ confidence intervals. Data cover the time until the last zoea $\mathrm{V}$ had moulted to the megalopa stage or died. Orange dots (megalopa stage) along the $x$-axis hide all zoea stages (I to V) that are still under development to the next stage or died salinity $\left(2^{\text {nd }}\right.$ degree polynomial regression: $F_{(2,149)}=2, \mathrm{p}=0.13, \mathrm{R}^{2}=$ 0.03 ; Figs. $2 \mathrm{~b} \& 3$ ).

In general, the highest proportion of survivors across zoea stages were recorded at salinities 25 and 30, followed by salinities 20 and 35 (Figs. 3 \& S2a-e, Table S2). In this regard, the optimum salinity was 26.5 . At salinity 0 , zoea I suffered from abrupt mortality during the first $24 \mathrm{~h}$ and no larva moulted to the next stage (Figs. 3 \& S2a). At salinity 5, $4.7 \pm 3 \%$ (mean $\pm \mathrm{SD}$ ) of larvae moulted to zoea II, but none of them reached the zoea III stage (Figs. $3 \&$ S2b-c). At salinity 10, larvae could not moult beyond zoea III, while they reached zoea V at salinity 15 (Figs. 3 \& S2b-d).

\subsection{Feeding rates of juveniles and adults}

There were significant effects of salinity on feeding rates in juveniles and adults of $H$. takanoi. Feeding rates in juveniles increased significantly with increasing salinity $\left(2^{\text {nd }}\right.$ degree polynomial regression: $F_{(2,32)}=$ 30, $\mathrm{p} \leq$ 0.001, $\mathrm{R}^{2}=0.65$; Fig. $4 \mathrm{a}$ ). In adults, food intake also increased between salinities 5 and 15, but then reached a plateau and remained constant across the remaining salinity levels $\left(2^{\text {nd }}\right.$ degree polynomial regression: $F_{(2,18)}=27, \mathrm{p} \leq 0.001, \mathrm{R}^{2}=0.75$; Fig. 4b).

\subsection{Prevailing salinity regimes in Kiel Fjord}

Median (mean) salinity in Kiel Fjord over the entire experiment was 16.8 (17.0), ranging between 8.4 and 24.7 (Fig. 5). Salinity was 15.7 (15.9) in waters up to $1 \mathrm{~m}$ below surface, 16.5 (16.9) at $7 \mathrm{~m}$ depth and 18.1 (18.4) at $18 \mathrm{~m}$ depth. Salinity varied among seasons and was lowest in spring and summer when larvae of $H$. takanoi hatch in Kiel Fjord, and high- 

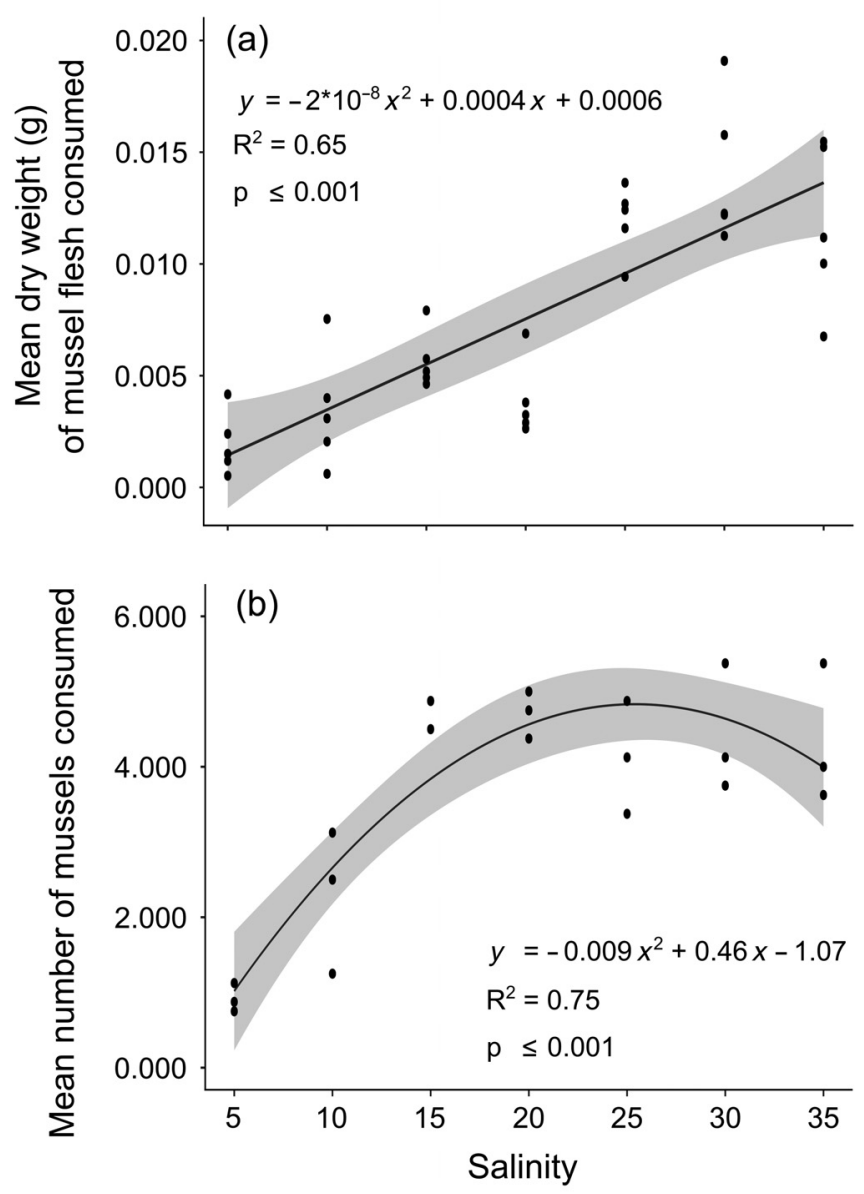

Fig. 4. Influence of salinity (0-35) on feeding rates in (a) juveniles ( $\mathrm{n}=5$ ) and (b) adults $(\mathrm{n}=3)$ of $H$. takanoi from Kiel Fjord. Black dots represent the mean food uptake for each individual crab during $17 \mathrm{~d}$. Data were analysed using $2^{\text {nd }}$ degree polynomial regressions. Grey areas represent the $95 \%$ confidence intervals of the fitted lines

est in autumn and winter when juveniles are found (Fig. 5d).

\section{DISCUSSION}

Our experiments show that the larval, juvenile and adult stages of Hemigrapsus takanoi, a species that recently arrived in the southwestern Baltic Sea, are affected differently by salinity. Although larvae of this crab species were more sensitive to low-salinity stress than adults, they successfully developed to the megalopa stage as long as salinities were equal to or above 20. Neither the duration of development to the megalopa nor the probability of reaching this stage differed across higher salinities $(\geq 20)$; however, survival and success in development were highest at a salinity of 25. In contrast to larvae, juveniles and adults were more robust to reduced salinities and showed $100 \%$ survival in response to salinities between 5 and 35. Feeding rates, however, also differed between salinity levels. Generally, feeding increased with increasing salinity. In adults, however, feeding rates remained constant at salinities $\geq 15$.

In general, increasing salinity favoured larval development of $H$. takanoi from Kiel Fjord. All larvae died before reaching the megalopa stage when they were reared at salinities below 20. In contrast to our findings, Mingkid et al. (2006b), who tested a salinity gradient from 5 to 35 (5 salinity unit steps) in Tokyo Bay, showed that 1.4 and $30 \%$ of $H$. takanoi larvae successfully moulted into megalopae at salinities as low as 10 and 15, respectively.

The discrepancy in the lower salinity thresholds of the present study $(\geq 20)$ and Mingkid et al. (2006b) ( $\geq 15$ ) suggests that $H$. takanoi larvae have a narrower salinity range in their new habitat than in their native range. Supporting this, Kiel Fjord larvae survived and developed best at salinities between 25 and 30 . In contrast, Mingkid et al. (2006b) demonstrated the highest percentage of larval development to megalopae at a salinity of 20. Seemingly, Kiel Fjord $H$. takanoi larvae prefer higher salinities than larvae from a native-range population (Mingkid et al. 2006a) and a similar pattern was observed for gammarid crustaceans (Pauli \& Briski 2018). Between-population differences in salinity tolerance have also been shown for other crustacean taxa (Ojaveer et al. 2007). For example, Carcinus maenas from the Baltic Sea have a higher capacity to hyper-osmoregulate than individuals from a North Sea population (Theede 1969). This potential shift in salinity preference might be the result of adaptations at the population level to different local environmental conditions after arrival in a new habitat, as shown in a study on 22 populations of 8 gammarid species from different regions (Paiva et al. 2018), or may have occurred during the invasion process. A recent study by Landeira et al. (2020) showed that survival of newly hatched $H$. takanoi zoea I larvae from Tokyo Bay decreases with decreasing salinity. In addition, a slowing of their swimming speed, accompanied by random swimming trajectories, was observed at salinities below 20. This suggests that low salinities not only restrict invasiveness, but also limit the local dispersal capacity of $H$. takanoi.

Within Kiel Fjord, H. takanoi must tolerate salinities between 8 and 25, while salinities range between 7 and 35 in the native range of $H$. takanoi, e.g. Tokyo Bay (Mingkid et al. 2006a). The salinity tolerance thresholds and performance maxima at salini- 

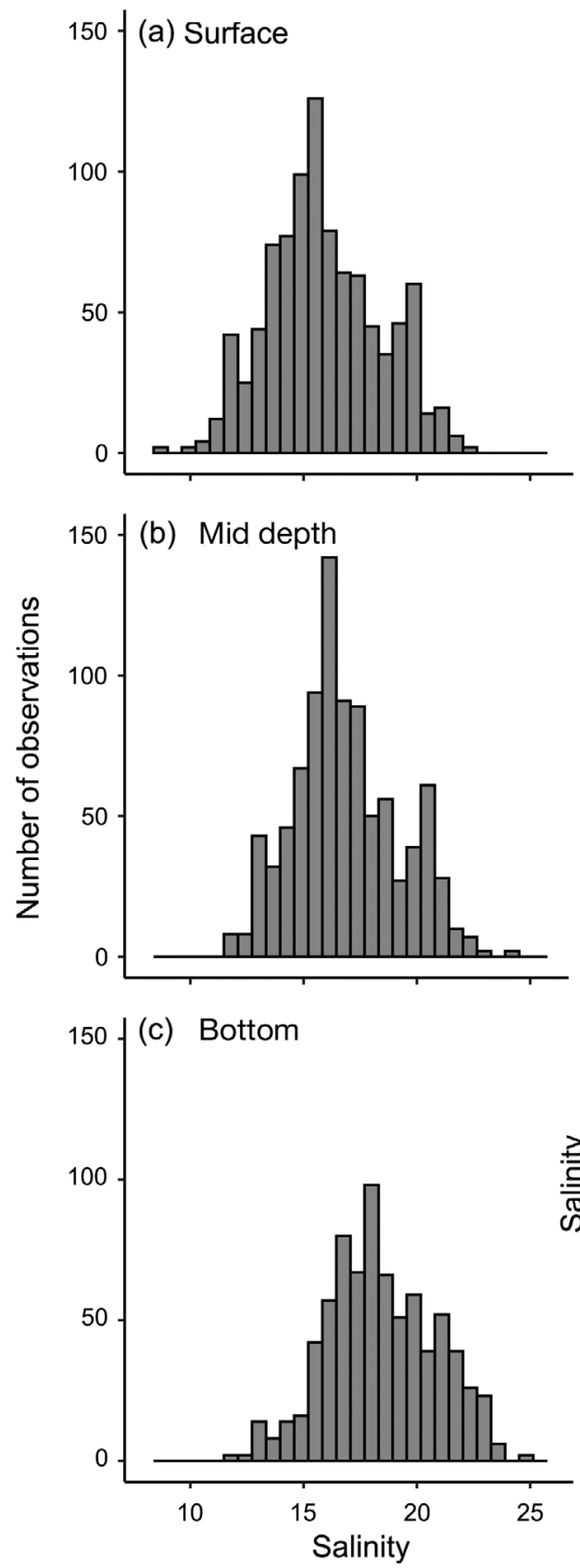

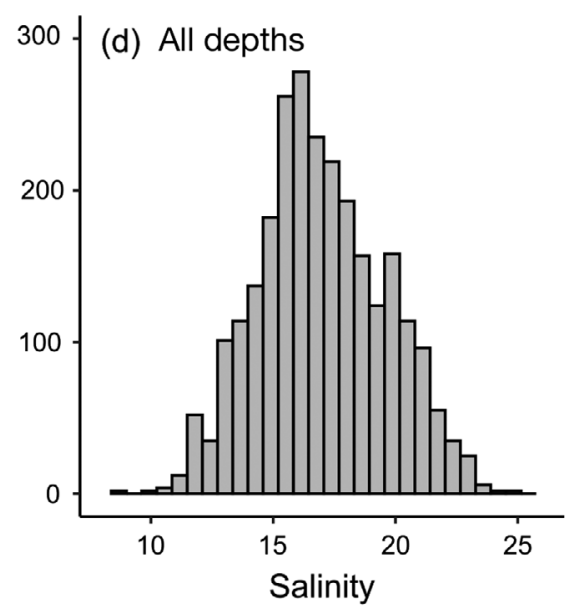

(e)

Adults

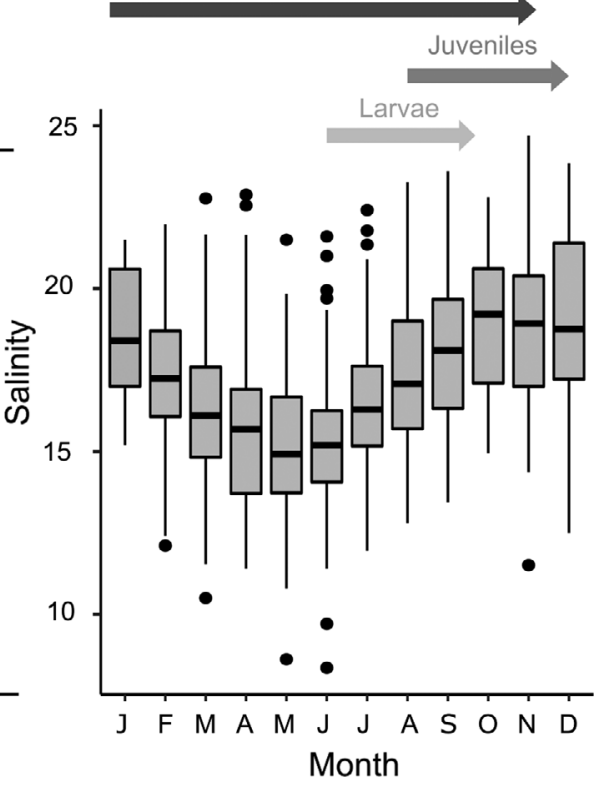

Fig. 5. Salinity regimes of the inner Kiel Fjord based on a 13 yr dataset collected between November 2005 and December 2018 within the Kiel Fjord Zooplankton-fish larvae time series at GEOMAR. Data are presented in frequency plots for (a) surface (surface to $1 \mathrm{~m} ; \mathrm{n}=939$ ), (b) mid depth ( $7 \mathrm{~m} ; \mathrm{n}=902$ ) and (c) bottom (18 $\mathrm{m} ; \mathrm{n}=763$ ) waters, and (d) for all water depths combined. (e) Seasonal salinity patterns among all years and depth layers are presented in boxplots showing medians (black lines in the boxes), upper (75 percentile) and lower (25 percentile) quartiles, the non-outlier range (whiskers) and outliers (black dots).

The approximate time range of occurrence of larvae, juveniles and adults is indicated by arrows (above the plot)

ties of 20 and 25, respectively, identified in this study, indicate that the invasion process rather than adaptations to the new environment determined osmotic stress tolerance in the Kiel Fjord H. takanoi population. The fact that Baltic Sea $H$. takanoi populations are genetically very similar to those from the North
Sea (Geburzi et al. 2020) suggests that the introduction of $H$. takanoi into the Baltic Sea was mediated by the transport of larvae in ballast water of ships from the North Sea or from European Atlantic ports (Geburzi et al. 2015). Alternatively, larvae could have been transported into the Baltic Sea by advec- 
tion from the Kattegat due to strong westerly winds pushing highly saline waters into the Baltic Sea (Lehmann \& Javidpour 2010). It is generally thought that the European populations of H. takanoi arose from multiple independent introductions into the French Atlantic, French British Channel, and Dutch Wadden Sea (Markert et al. 2014). In addition, the North Sea populations might trace back to a secondary introduction of individuals from a donor population already adapted to marine conditions (Makino et al. 2018, Geburzi et al. 2020). Furthermore, the North Sea populations could then have adapted themselves to fully marine conditions for $>25 \mathrm{yr}$, while the Kiel Fjord population presumably only had $\sim 5$ yr to adapt to local environmental conditions. However, detailed studies on the osmoregulation capacity of $H$. takanoi larvae from populations along the invasion gradient would be needed to confirm this hypothesis.

We found larval duration to be only marginally impacted by osmotic stress at salinities of 20 and higher. This has also been found in other crab species such as the mangrove crab Ucides cordatus from the Caeté Estuary Northern Brazil (Diele \& Simith 2006) and the mud crab Scylla olivacea from estuaries and creeks in Thailand (Jantrarotai et al. 2002). Kiel Fjord $H$. takanoi larvae in the present experiment developed generally slower (larval duration of 35-37 d) than individuals of the same species from its native range ( 16-21 d; Mingkid et al. 2006b). Diele \& Simith (2006) suggest that variation in the time needed for development in $U$. cordatus could be due to diet. In our study, we fed larvae with Artemia sp. nauplii only, while Mingkid et al. (2006b) provided rotifers for food until the zoea III stage was reached, after which a mixture of Artemia sp. nauplii and rotifers was offered. However, differences between the 2 studies could also be explained by differences in temperature during incubation of the larvae, i.e. $20^{\circ} \mathrm{C}$ herein and $24^{\circ} \mathrm{C}$ in Mingkid et al. (2006b) (see also Epifanio et al. 1998, Spitzner et al. 2019 for temperature effects on crustacean larval development).

In contrast to larvae, juveniles and adults of Kiel Fjord $H$. takanoi tolerated a wide range of salinities from 5 to 35, at least for the $2 \mathrm{wk}$ these individuals were exposed to the stress gradient. In contrast, freshwater conditions led to $100 \%$ mortality in juveniles and adults within 2 and $4 \mathrm{~d}$, respectively. Shinji et al. (2009) exposed adult $H$. takanoi from the native range (Tokyo Bay) to salinities from 0 to 40 for $8 \mathrm{~h}$ to study their immediate physiological responses. Although no mortality was observed over the short incubation period at any salinity, oxygen consumption and ammonia excretion levels were remarkably increased at a salinity of 0 , while no significant differences were detected among all other salinity levels (Shinji et al. 2009). Data from the congeneric H. sanguineus showed a higher survival probability at a salinity of 5 compared to a salinity of 1 , mainly explained by the ability to maintain internal haemolymph osmolality under osmotic stress at a salinity of 5 for several days (Hudson et al. 2018). Since osmoregulation is an energetically demanding process (Anger 1991), future research is required to study the consequences of osmotic stress on $H$. takanoi in the long-term.

Feeding rates in both juvenile and adult $H$. takanoi were strongly influenced by salinity, yet in different ways. In juveniles, feeding decreased linearly with decreasing salinity. These findings are in line with observations made of juvenile crabs of the species Portunus trituberculatus (Shentu et al. 2015). Feeding rates in adults, however, were not affected across the salinity range from 15 to 35 . Contrary to our results, Urbina et al. (2010) showed that feeding rates in adult $H$. crenulatus decreased with increasing salinities. They interpreted this as a compensatory mechanism to face the increased energy costs that emerged from excretion and respiration during osmoregulation activity. In general, a decrease in feeding rates as a reaction to environmental stress has been observed in different marine invertebrate taxa, such as cnidarians (Podbielski et al. 2016), crustaceans (Appelhans et al. 2012), molluscs (Zhang et al. 2016) and echinoderms (Stumpp et al. 2012).

In decapod crustaceans, moulting is an energy consuming process, accompanied by an increase in metabolic rate (Skinner 1962). The process is modulated by many environmental factors like temperature, photoperiod and salinity, and it involves many physiological changes in the crabs themselves (Urzúa \& Urbina 2017). The results presented here do not reflect any potential effects of moulting as a response to the salinities we applied, since all individuals were intermoult crabs.

While adults of $H$. takanoi tolerated the salinity range of 5 to 35, our results suggest a clear bottleneck in larval development. The critical threshold for H. takanoi larvae to complete their full development at $20^{\circ} \mathrm{C}$ (common summer Kiel Fjord temperature) was found to be between 15 and 20, while in Kiel Fjord (southwestern Baltic Sea) salinities range between 8 and 25 (Fig. 5). The salinity regimes recorded at different water depths between 2005 and 2018 would therefore allow juveniles and adults of $H$. takanoi to thrive. In 2017, ovigerous females appeared in late June, at salinities higher than 15, and 
larval development probably continued into September and October, when salinities were still above 17 (Nour et al. 2020). In line with this, large numbers of juveniles were observed in November 2018, when salinities were around 19 (O. M. Nour pers. obs.). Between 2005 and 2018, the median salinity (surface to a depth of $7 \mathrm{~m}$ ) in Kiel Fjord during the reproductive season, when hatching and development of larvae takes place (June to October), ranged from 8.4 to 22 (Fig. 5). This indicates that Kiel Fjord salinity conditions can allow successful larval development, at least during years with higher salinities. However, to be able to identify years in which successful larval development can occur more reliably, experiments investigating the salinity range between 15 and 20 are necessary. Salinity thresholds for larval development have been observed in other species from Kiel Fjord (Eriocheir sinensis: Anger 1991, C. maenas: Cieluch et al. 2004, Asterias rubens: Casties et al. 2015). Hence, interannual salinity fluctuations recorded in Kiel Fjord might play a crucial role in stabilizing the population dynamics of its keystone species (Casties et al. 2015). A decline in salinity below a critical threshold during the spawning season of $A$. rubens, for example, might inhibit larval development (Casties et al. 2015). We do not have sufficient data about the structure of the $C$. maenas populations in the Baltic Sea and about seasonality in their reproduction to say whether salinity could also play a role in C. maenas larval development. However, it is known from other European coasts that there are 2 main peaks in egg production of C. maenas (early summer and late autumn; Torres et al. 2020), and larvae require salinities $>15$ to complete their development (Anger et al. 1998). If this is also the case for the Baltic Sea population, it is plausible to assume that even with the expected desalination of the Baltic Sea (Gräwe et al. 2013), larvae from autumn embryos (mean salinity > 15; Fig. 5) can maintain the population. In contrast, $H$. takanoi in the Baltic Sea shows only one peak in egg production and that is in summer (Nour et al. 2020). It is therefore likely that a failure in recruitment will occur under the future Baltic Sea conditions, which consequently could cause the extinction of $H$. takanoi populations.

H. takanoi larvae are planktonic and likely move towards the water surface immediately after hatching (Landeira et al. 2019). In the southwestern Baltic Sea, surface seawater is generally less saline than deeper waters (Fig. 5), meaning Kiel Fjord H. takanoi larvae are facing a dilemma. On one hand, surface waters show a higher phytoplankton abundance and consequently also a higher abundance of small zoo- plankton organisms (Anger 2003), which could serve as a food source for larvae. On the other hand, the salinity regimes in surface waters potentially restrict successful development. However, it remains to be investigated if $H$. takanoi larvae can meet their salinity and feeding requirements by actively migrating through the water column.

The findings of the present study suggest that $H$. takanoi populations are limited in their distribution to the southwestern Baltic Sea, mainly due to their larval salinity sensitivity. Future monitoring of the spatial and temporal distribution of $H$. takanoi larvae along the salinity gradient from the southwestern Baltic Sea into the Baltic Proper will reveal whether this assumption proves correct. Whether the prolongation of larval development ( 35-37 d) observed in this study, in comparison to the time needed for larval development in native habitats ( 16-21 d; Mingkid et al. 2006b), is an advantage for H. takanoi dispersal and population establishment in the further northern and eastern Baltic Sea is unclear. Longer larval development can have important consequences for recruitment success (Sulkin \& McKeen 1994) by increasing natural mortality risk due to factors such as predation (Morgan 1995). Nevertheless, a longer developmental period increases the probability that larvae will spread and reach appropriate substrates prior to metamorphosis (Jackson \& Strathmann 1981), which could allow the species to colonize new areas and would enhance gene flow among local populations (Díaz \& Bevilacqua 1986). Numerous studies have revealed that larval ability to cope with salinities outside the optimum range is also strongly influenced by temperature (Anger 1991, Epifanio et al. 1998). In nature, environmental stresses such as warming and desalination do not usually occur in isolation and can therefore interactively affect organisms (Epifanio et al. 1998). Hence, studying the combined effects of these 2 factors is important to assess the response of $H$. takanoi populations to the future abiotic changes expected to occur in the Baltic Sea.

The fact that female brachyuran crabs brood externally may allow their embryos to acclimate to low salinities during embryogenesis and this could potentially increase their ability to tolerate low salinities after hatching (Giménez \& Torres 2002). In our larvae experiment, we collected all ovigerous crabs from the same locality in Kiel Fjord and they were, prior to experiments, kept in the laboratory at the same salinity that prevailed in the fjord $(\sim 20)$. It is possible that larvae from regions with even lower salinities would show higher survival rates than 
those observed in our experiments. However, in $H$. crenulatus, embryogenesis is not completed at a salinity of 5 because females allocate energy to osmoregulation and therefore produce less egg yolk (Urzúa et al. 2018). Similar salinity-related constraints on embryo development have been observed in C. maenas. Even though C. maenas from North Sea populations completed their larval development at a salinity of 20 under laboratory conditions when ovigerous females were kept at a salinity of $\sim 32$ (Spitzner et al. 2019), females discarded their eggs when they were incubated at salinity of 20 (G. Torres unpubl. data, in Torres et al. 2020). With larvae of $C$. maenas, negative effects of low salinities on survival and development time were mitigated by high temperatures (Spitzner et al. 2019). However, Torres et al. (2020) found no evidence of embryonic acclimation to low salinities in C. maenas from North Wales, UK, while, in contrast to this, acclimation to low salinities during embryogenesis limited the thermal mitigation of low salinity stress for zoea I larvae. This thermal mitigate limitation could be related to the depletion of energy reserves during embryo development, which occurred when ovigerous females were exposed to low salinities (Giménez \& Anger 2001). It resulted in decreased larval survival and reduced development rates (Torres et al. 2020). Low salinity in the maternal habitat of $H$. takanoi might produce larvae that perform sub-optimal swimming and have lowered survival rates (Landeira et al. 2020). Given these possible maternal effects, the best offspring performance might occur when conditions in maternal and offspring environments are similar (Uller et al. 2013). Hence, assessing the response of $H$. takanoi offspring to salinity stress while considering possible maternal effects will require further studies. Since juvenile and adult stages of $H$. takanoi have the potential to invade the central Baltic Proper, which has bottom salinities of 8 to 6 (HELCOM 2018), the entire reproductive cycle of $H$. takanoi may take place in this lower salinity region if the species manages to locally adapt to these conditions. However, physiological responses of this species to salinity stress still need to be investigated in studies that cover a longer period of its lifetime.

\section{CONCLUSIONS}

Previous studies have revealed that non-native species are generally tolerant of a wide range of salinities and tend to be more resistant to stressful conditions than native species (Lenz et al. 2011, Paiva et al. 2018). Herein, we showed a strong influence of salinity on the earliest stages of the recent invader $H$. takanoi. The development of $H$. takanoi larvae was only completed in salinities between 20 and 35, which contrasts with the salinity tolerance of larvae from the native range of this species (Mingkid et al. 2006b). Reasons for this discrepancy are undetermined, but could potentially relate to the previous adaptation of $H$. takanoi populations established in the southwestern Baltic Sea to fully marine conditions during a secondary spread in the invasion process. North Sea habitats, which are fully marine, could have served as stepping stones prior to the introduction of this species into Kiel Fjord (Geburzi et al. 2020). Juveniles and adults can tolerate salinities as low as 5, but their feeding rates declined at low salinities, with possible long-term implications for their fitness. Although field observations showed that the southwestern Baltic Sea is a suitable habitat for $H$. takanoi (Nour et al. 2020), salinity likely represents a hurdle for a further invasion into the central and eastern Baltic Sea, in particular for the larval stages of $H$. takanoi. According to future climate scenarios (Meier et al. 2012), which predict a reduction in salinity across the Baltic Sea by the end of the century, Kiel Fjord will most likely experience a decline in salinity of 2 units on average (Gräwe et al. 2013), which could lead to more frequent and longer phases during the year with salinities outside the tolerance boundaries of larval $H$. takanoi. The question remains whether the species will be able to undergo full larval development in the future, if it cannot adapt to the changes predicted for this region.

Data availability. Data used in the present study are available at PANGAEA (https://doi.pangaea.de/10.1594/PANGAEA. 918306).

Acknowledgements. We thank Dr. Gabriela Torres for advice on larval rearing techniques and Björn Buchholz for technical assistance. O.M.N. acknowledges the financial support of the German Academic Exchange Service (DAAD) through the German Egyptian Research Long-term Scholarship Programme (GERLS) 2015/16 (57147166). This study was carried out and funded by GEOMAR Helmholtz Centre for Ocean Research Kiel, Germany. Authors declare no conflicts of interest. All applicable international, national, and/or institutional guidelines for sampling, care, and experimental use of organisms in the study have been followed. Methods and protocols were approved by the regulatory committee on the ethics of animal experiments of Schleswig-Holstein, Germany, under the permit number 1101. All possible actions were taken to reduce animal suffering and stress during handling and sampling. O.M.N., C.P., M.W. and M.S. designed the study. O.M.N. performed the experiments. O.M.N., C.P., M.L., and M.S. analysed and visualized the data. C.C. provided the long-term time series 
salinity data. O.M.N., C.P. and M.S. wrote the first draft of the manuscript. All authors contributed to the final draft of the manuscript.

\section{LITERATURE CITED}

Anger K (1991) Effects of temperature and salinity on the larval development of the Chinese mitten crab Eriocheir sinensis (Decapoda: Grapsidae). Mar Ecol Prog Ser 72: 103-110

Anger K (2003) Salinity as a key parameter in the larval biology of decapod crustaceans. Invertebr Reprod Dev 43: 29-45

Anger K, Spivak E, Luppi T (1998) Effects of reduced salinities on development and bioenergetics of early larval shore crab, Carcinus maenas. J Exp Mar Biol Ecol 220: 287-304

Anger K, Spivak E, Luppi T, Bas C, Ismael D (2008) Larval salinity tolerance of the South American salt-marsh crab, Neohelice (Chasmagnathus) granulata: physiological constraints to estuarine retention, export and reimmigration. Helgol Mar Res 62:93-102

*Appelhans YS, Thomsen J, Pansch C, Melzner F, Wahl M (2012) Sour times: seawater acidification effects on growth, feeding behaviour and acid-base status of Asterias rubens and Carcinus maenas. Mar Ecol Prog Ser 459: 85-98

Asakura A, Watanabe S (2005) Hemigrapsus takanoi, new species, a sibling species of the common Japanese intertidal crab $H$. penicillatus (Decapoda: Brachyura: Grapsoidea). J Crustac Biol 25:279-292

Ashelby CW, Sewell J, Rostron J, Shrubsole R, Child T, Clark PF (2017) Evidence for the invasion and successful establishment of Hemigrapsus takanoi Asakura \& Watanabe, 2005 (Decapoda, Varunidae) in Great Britain. Crustaceana 90:695-708

Bas CC, Spivak ED (2000) Effect of salinity on embryos of two southwestern Atlantic estuarine grapsid crab species in vitro. J Crustac Biol 20:647-656

Canning-Clode J (2016) Biological invasions in changing ecosystems: vectors, ecological impacts, management and predictions. De Gruyter Open, Warsaw

* Casties I, Clemmesen C, Melzner F, Thomsen J (2015) Salinity dependence of recruitment success of the sea star Asterias rubens in the brackish Western Baltic Sea. Helgol Mar Res 69:169-175

* Charmantier G (1998) Ontogeny of osmoregulation in crustaceans: a review. Invertebr Reprod Dev 33:177-190

* Charmantier G, Charmantier-Daures M, Anger K (1998) Ontogeny of osmoregulation in the grapsid crab Amarses miersii (Crustacea: Decapoda). Mar Ecol Prog Ser 164: 285-292

* Charmantier G, Giménez L, Charmantier-Daures M, Anger K (2002) Ontogeny of osmoregulation, physiological plasticity, and larval export strategy in grapsid crab Chasmagnathus granulata (Crustacea, Decaopda). Mar Ecol Prog Ser 229:185-194

Cieluch U, Anger K, Aujoulat F, Buchholz F, CharmantierDaures M, Charmantier G (2004) Ontogeny of osmoregulatory structures and functions in the green crab Carcinus maenas (Crustacea, Decapoda). J Exp Biol 207:325-336

de Jesus de Brito Simith D, de Souza AS, Maciel CR, Fernando M, Abrunhosa FA, Diele K (2012) Influence of salinity on the larval development of the fiddler crab Uca voca- tor (Ocypodidae) as an indicator of ontogenetic migration towards offshore waters. Helgol Mar Res 66:77-85

Díaz H, Bevilacqua M (1986) Larval development of Aratus pisonii (Milne Edwards) (Brachyura, Grapsidae) from marine and estuarine environments reared under different salinity conditions. J Coast Res 2:43-49

Diele K, Simith DJB (2006) Salinity tolerance of Northern Brazilian mangrove crab larvae, Ucides cordatus (Ocypodidae): necessity for larval export? Estuar Coast Shelf Sci 68:600-608

Epifanio CE, Dittel AI, Park S, Schwalm S, Fouts A (1998) Early life history of Hemigrapsus sanguineus a nonindigenous crab in the Middle Atlantic Bight (USA). Mar Ecol Prog Ser 170:231-238

*Galil BS, Marchini A, Occhipinti-Ambrogi A, Minchin D, Narščius A, Ojaveer H, Olenin S (2014) International arrivals: widespread bioinvasions in European Seas. Ethol Ecol Evo Sci 26:152-171

Geburzi JC, Graumann G, Köhnk S, Brandis D (2015) First record of the Asian crab Hemigrapsus takanoi Asakura \& Watanabe, 2005 (Decapoda, Brachyura, Varunidae) in the Baltic Sea. BioInvasions Rec 4:103-107

Geburzi JC, Brandis D, Buschbaum C (2018) Recruitment patter, low cannibalism and reduced interspecific predation contribute to high invasion success of two Pacific crabs in northwestern Europe. Estuar Coast Shelf Sci 200:460-472

* Geburzi J, Ewwes-Saucedo C, Brandis D, Hartl GB (2020) Complex patterns of secondary spread without loss of genetic diversity in invasive populations of the Asian shore crab Hemigrapsus takanoi (Decapoda) along European coasts. Mar Biol 167:180

Giménez L, Anger K (2001) Relationships among salinity, egg size, embryonic development, and larval biomass in the estuarine crab Chasmagnathus granulata Dana, 1851. J Exp Mar Biol Ecol 260:241-257

*Giménez L, Torres G (2002) Larval growth in the estuarine crab Chasmagnathus granulata: the importance of salinity experienced during embryonic development, and the initial larval biomass. Mar Biol 141:877-885

Gittenberger A, Rensing M, Stegenga H, Hoeksema B (2010) Native and non-native species of hard substrata in the Dutch Wadden Sea. Nederlandse Faunistische Mededelingen 33:21-76

Gollasch S (1998) The Asian decapod Hemigrapsus penicillatus (de Haan, 1835) (Grapsidae, Decapoda) introduced in European waters: status quo and future perspective. Helgol Meeresunters 52:359-366

Gräwe U, Friedland R, Burchard H (2013) The future of the western Baltic Sea: two possible scenarios. Ocean Dyn 63:901-921

HELCOM (2018) State of the Baltic Sea-Second HELCOM holistic assessment 2011-2016. Baltic Sea Environment Proceedings, Helsinki

Kudson DM, Sexton DJ, Wint D, Capizzano C (2018) Physiological and behavioral response of the Asian shore crab, Hemigrapsus sanguineus, to salinity: implications for estuarine distribution and invasion. PeerJ 6

Jackson GA, Strathmann RR (1981) Larval mortality from offshore mixing as a link between precompetent and competent periods of development. Am Nat 118:16-26

Jantrarotai P, Taweechuer K, Pripanapong S (2002) Salinity levels on survival rate and development of mud crab (Scylla olivacea) from zoea to megalopa and from megalopa to crab stage. Witthayasan Kasetsat Witthayasat 36 : 278-284 
Jaspers C, Møller LF, Kiørboe T (2011) Salinity gradient of the Baltic Sea limits the reproduction and population expansion of the newly invaded comb jelly Mnemiopsis leidyi. PLOS ONE 6:e24065

Kassambara A, Marcin KM, Przemyslaw BP (2019) Survminer: drawing survival curves using 'ggplot2'. R package version 0.4.6. www.sthda.com/english/rpkgs/survminer/

Koram SS (2019) Key concept of quadratic functions and inequalities, 1st edn. Springer Series in Geomechanics and Geoengineering 13:9-22

Krauss W (2001) Baltic Sea circulation. In: Steele J, Thorpe $\mathrm{S}$, Turekian K (eds) Encyclopedia of ocean sciences. Academic Press, San Diego, CA, p 236-244

Landeira JS, Cuesta JA, Tanaka Y (2019) Larval development of the brush-clawed shore crab Hemigrapsus takanoi Asakura \& Watanabe, 2005 (Decapoda, Brachyura, Varunidae). J Mar Biol Assoc UK 99:1153-1164

Landeira JM, Liu B, Omura T, Akiba T, Tanaka Y (2020) Salinity effects on the first larval stage of the invasive crab Hemigrapsus takanoi: survival and swimming patterns. Estuar Coast Shelf Sci 245:106976

* Lehmann A, Javidpour J (2010) Potential pathways of invasion and dispersal of Mnemiopsis leidyi A. Agassiz 1865 in the Baltic Sea. Hydrobiologia 649:107-114

Lenz M, da Gama BA, Gerner NV, Gobin J and others (2011) Non-native marine invertebrates are more tolerant towards environmental stress than taxonomically related native species: results from a globally replicated study. Environ Res 111:943-952

Keppäkoski E, Gollasch S, Gruszka P, Ojaveer H, Olenin S, Panov V (2002) The Baltic - a sea of invaders. Can J Fish Aquat Sci 59:1175-1188

Lockwood BL, Somero GN (2011) Invasive and native blue mussels (genus Mytilus) on the California coast: the role of physiology in a biological invasion. J Exp Mar Biol Ecol 400:167-174

Makino W, Miura O, Kaiser F, Geffray M, Katsube T, Urabe $\mathrm{J}$ (2018) Evidence of multiple introductions and genetic admixture of the Asian brush-clawed shore crab Hemigrapsus takanoi (Decapoda: Brachyura: Varunidae) along the Northern European coast. Biol Invas 20: 825-842

Markert A, Raupach MJ, Segelken-Voigt A, Wehrmann A (2014) Molecular identification and morphological characteristics of native and invasive Asian brush-clawed crabs (Crustacea: Brachyura) from Japanese and German coasts: Hemigrapsus penicillatus (De Hann, 1835) versus Hemigrapsus takanoi Asakura \& Watanabe 2005. Org Divers Evol 14:369-382

Meier HEM, Hordoir R, Andersson HC, Dieterich C and others (2012) Modeling the combined impact of changing climate and changing nutrient loads on the Baltic Sea environment in an ensemble of transient simulations for 1961-2099. Clim Dyn 39:2421-2441

Mingkid WM, Akiwa S, Watanabe S (2006a) Morphological characteristics, pigmentation, and distribution of the sibling penicillate crabs, Hemigrapsus penicillatus (de Haan 1835) and H. takanoi Asakura \& Watanabe, 2005 (Decapoda, Brachyura, Grapsidae) in Tokyo Bay. Crustaceana 79:1107-1121

Mingkid WM, Masashi YM, Watanabe S (2006b) Salinity tolerance of larvae in the penicillate crab Hemigrapsus takanoi (Decapoda: Brachyura: Grapsidae). Mer (Paris) $44: 17-21$

Morgan SG (1995) Life and death in the plankton: larval mor- tality and adaptation. In: McEdward L (ed) Ecology of marine invertebrate larvae. CRC Press, Boca Raton, FL, p 279-321

*Nour OM, Stumpp M, Morón SC, Barboza FR, Pansch C (2020) Population structure of the recent invader Hemigrapsus takanoi and prey size selection on Baltic Sea mussels. Aquat Invasions 15:297-317

Novo MS, Miranda RB, Bianchini A (2005) Sexual and seasonal variations in osmoregulation and ionoregulation in the estuarine crab Chasmagnathus granulatus (Crustacea, Decapoda). J Exp Mar Biol Ecol 323:118-137

* Occhipinti-Ambrogi A, Galil B (2010) Marine alien species as an aspect of global change. Adv Oceanol Limnol 1: $199-218$

Ojaveer H, Gollasch S, Jaanus A, Kotta J and others (2007) Chinese mitten crab Eriocheir sinensis in the Baltic Sea -a supply-side invader? Biol Invas 9:409-418

*Paavola M, Olenin S, Leppäkoski E (2005) Are invasive species most successful in habitats of low native species richness across European brackish water seas? Estuar Coast Shelf Sci 64:738-750

* Paiva F, Barco A, Chen Y, Mirzajani A and others (2018) Is salinity an obstacle for biological invasions? Glob Change Biol 24:2708-2720

*Pauli NC, Briski E (2018) Euryhalinity of Ponto-Caspian invader in their native and introduced regions. Aquat Invasions 13:439-447

* Podbielski I, Bock C, Lenz M, Melzner F (2016) Using the critical salinity (Scrit) concept to predict invasion potential of the anemone Diadumene lineata in the Baltic Sea. Mar Biol 163:1-15

R Development Core Team (2016) R: a language and environment for statistical computing. R Foundation for Statistical Computing, Vienna

* Reise K, Olenin S, Thieltges DW (2006) Are aliens threatening European aquatic coastal ecosystems? Helgol Mar Res 60:77-83

Reusch T, Chapman ARO (1997) Persistence and space occupancy by subtidal blue mussel patches. Ecol Monogr 67:65-87

Keusch TBH, Dierking J, Andersson HC, Bonsdorff E and others (2018) The Baltic Sea as a time machine for the future coastal ocean. Sci Adv 4:eaar8195

* Shentu J, Xu J, Ding Z (2015) Effects of salinity on survival, feeding behavior and growth of the juvenile swimming crab, Portunus trituberculatus (Miers, 1876). Chin J Oceanology Limnol 33:679-684

* Shinji J, Strussmann CA, Wilder MN, Watanabe S (2009) Short-term responses of the adults of the common Japanese intertidal crab, Hemigrapsus takanoi (Decapoda: Brachyura: Grapsoidea) at different salinities: osmoregulation, oxygen consumption, and ammonia excretion. J Crustac Biol 29:269-272

* Skinner DM (1962) The structure and metabolism of a crustacean integumentary tissue during a molt cycle. Biol Bull 123:635-647

* Spitzner F, Giménez L, Meth R, Harzsch S, Torres G (2019) Unmasking ontogenetic and intraspecific variation in offspring responses to multiple environmental drivers. Mar Biol 166:112

Stumpp M, Trübenbach K, Brennecke D, Hu MY, Melzner F (2012) Resource allocation and extracellular acid-base status in the sea urchin Strongylocentrotus droebachiensis in response to $\mathrm{CO}_{2}$ induced seawater acidification. Aquat Toxicol 110-111:194-207 
Sulkin SD, McKeen G (1994) Influence of temperature on larval development of four co- occurring species of the brachyuran genus Cancer. Mar Biol 118:593-600

Theede H (1969) Einige neue aspekte bei der osmoregulation von Carcinus maenas. Mar Biol 2:114-120

Therneau TM (2015) A package for survival analysis in S, version 2.38. https://CRAN.R-project.org/package=survival

Thomsen J, Haynert K, Wegner KM, Melzner F (2015) Impact of seawater carbonate chemistry on the calcification of marine bivalves. Biogeosciences 12:4209-4220

Thomsen J, Ramesh K, Sanders T, Belich M, Melzner F (2018) Calcification in a marginal sea - influence of seawater $\left[\mathrm{Ca}^{2+}\right]$ and carbonate chemistry on bivalve shell formation. Biogeosciences 15:1469-1482

Torres G, Thomas DN, Whiteley NM, Wilcockson D, Giménez L (2020) Maternal and cohort effects modulate offspring responses to multiple stressors. Proc R Soc B 287:20200492

Tsiamis K, Palialexis A, Stefanova K, Gladan ZN, Skejić S, Despalatović M and others (2019) Non-indigenous species refined national baseline inventories: a synthesis in the context of the European Union's marine strategy framework directive. Mar Pollut Bull 145:429-435

Uller T, Nakagawa S, English S (2013) Weak evidence for anticipatory parental effects in plants and animals. J Evol Biol 26:2161-2170

Urbina M, Paschke K, Gebauer P, Chaparro OR (2010) Physiological energetics of the estuarine crab Hemigrapsus cre-

Editorial responsibility: Bernard Sainte-Marie,

Mont-Joli, Quebec, Canada

Reviewed by: 3 anonymous referees nulatus (Crustacea: Decapoda: Varunidae): responses to different salinity levels. J Mar Biol Assoc UK 90:267-273

*Urzúa Á, Urbina M (2017) Ecophysiological adaptations to variable salinity environments in the crab Hemigrapsus crenulatus from the Southeastern Pacific coast: sodium regulation, respiration and excretion. Comp Biochem Physiol A Mol Integr Physiol 210:35-43

* Urzúa Á, Bascur M, Guzmán F, Urbina M (2018) Carry-over effects modulated by salinity during the early ontogeny of the euryhaline crab Hemigrapsus crenulatus from the Southeastern Pacific coast: development time and carbon and energy content of offspring. Comp Biochem Physiol A Mol Integr Physiol 217:55-62

* van den Brink AM, Wijnhoven S, McLay CL (2012) Competition and niche segregation following the arrival of Hemigrapsus takanoi in the formerly Carcinus maenas dominated Dutch delta. J Sea Res 73:126-136

*van den Brink A, Godschalk M, Smaal A, Lindeboom H, McLay C (2013) Some like it hot: the effect of temperature on brood development in the invasive crab Hemigrapsus takanoi (Decapoda: Brachyura: Varunidae). J Mar Biol Assoc UK 93:189-196

Khang H, Shin PKS, Cheung SG (2016) Physiological responses and scope for growth in a marine scavenging gastropod, Nassarius festivus (Powys, 1835), are affected by salinity and temperature but not by ocean acidification. ICES J Mar Sci 73:814-824

Submitted: October 23, 2020

Accepted: March 23, 2021

Proofs received from author(s): July 18, 2021 